\title{
DETERMINANTS AND CONSEQUENCES OF SOCIAL TRUST*
}

\author{
Michael R. Welch \\ Department of Sociology \\ University of Notre Dame \\ Roberto E. N. Rivera \\ Department of Sociology \\ University of Notre Dame
}

\author{
Brian P. Conway \\ Department of Sociology \\ National University of Ireland, Maynooth \\ Jennifer Yonkoski \\ Department of Sociology \\ University of Notre Dame
}

Paul M. Lupton

Wichita, Kansas

Russell Giancola

University of Colorado 
*This paper represents a revised version of a paper originally developed in SOC. 476/576, offered in the Department of Sociology, University of Notre Dame, Notre Dame, Indiana, 2001. The definitive version is available online at http://www.blackwell-synergy.com/toc/soin/75/4

\section{Introduction}

"Trust... is never to be taken for granted....In our relation to the world, trust is always in conflict with mistrust. ...yet if we are dominated by mistrust we cannot attend or interpret adequately, we cannot act accountably, and we will rupture, not strengthen, the solidarity of the community or communities we live in."

(Robert Bellah, Richard Madsen, William M. Sullivan, Ann Swidler, and Steven M. Tipton, The Good Society.)

In reflecting on the work of the theologian $\mathrm{H}$. Richard Niebuhr, Bellah and his colleagues recognize that they have unearthed a singularly important insight about the nature of human communities: namely, that such communities can not exist without at least some requisite level of trust among the actors whose interactions constitute the essence of social life. This insight has acquired even greater significance throughout the last decade, as social scientists have come to understand more fully the type of social 
resources that are necessary to sustain civil society and the democratic state (cf., Sztompka, 1999). Much of this attention has centered largely on the nature of social capital and its constituent elements, the most important of which is usually identified as social trust (e.g. Fukuyama, 1995; Hearn, 1997).

Despite this general attention, however, few studies have investigated this latter concept thoroughly (Fukuyama, 1995; Cook, 2001; Macy and Sztompka, 1999, being the major exceptions), and even the best of those have seldom examined the concept from different analytic levels and disciplinary viewpoints. None have provided a complete inventory of findings related to the concept.

We agree that the heightened interest sociologists have recently shown toward social trust is justified (Sztompka ,1999), and begin this review by examining the theoretical bases for such interest. Because we believe that social trust provides the cohesiveness necessary for the development of meaningful social relationships, we treat trust as reflecting the functioning heart of a healthy society, economy, and democratic polity. But to fully understand the nature and significance of trust we must first clarify the meanings attached to the concept and demonstrate precisely how it is used in the social sciences. In the remaining sections of this paper, we present an inventory of propositions that specify conditions which promote or depress levels of social trust in a variety of social settings at both micro and macro levels, and we examine the consequences of social trust in the same way. The final section of the paper explores some continuing questions about trust that should be useful for directing future investigations. 


\section{The Elusive Meaning of Social Trust}

It is a rare occasion when trust is not conflated with social capital. Much of the recent literature on social capital treats the two concepts as virtually synonymous (Wilson 1997, Brehm and Rahn 1997, Glaser, Laibson, Scheinkman and Soutter 2000, Arrow 2000, Putnam 2000). Indeed, Brehm and Rahn argue that social capital and trust are mutually reinforcing although social capital has a stronger effect on trust than trust has on social capital (Brehm and Rahn 1997, p. 1017). But what is the theoretical relationship between social capital and trust? That is often difficult to determine because the core foci of these concepts are frequently obfuscated by the multiple levels and dimensions of trust. A central purpose of this paper is to explore the concept of trust, particularly its relationship to social capital, and how trust is conceived from diverse social scientific perspectives. Given the way trust appears to be viewed from these different perspectives, we will argue that social capital is a byproduct of trust; examine precisely how trust relates to social capital; and, finally, discuss various components of trust.

The Economic Perspective: A Focus On Transactional Market Mechanisms

Although we are most interested in understanding how social scientists in general --particularly sociologists-- interpret the concept of trust, it is important to differentiate the sociological perspective from the economic perspective because the two have very different foci, and much of the recent literature on trust tends, at least implicitly, to adopt an economic perspective regarding social capital (Wilson 1997, Glaser et al. 2000, Krishna 2000, Putnam 2000). This economic emphasis is clearly exemplified in several particular studies.. 
Hardin (2001), for example, represents trust as a symbolic commodity and Misztal (1996) goes so far as to assert that trust is a public good necessary for the success of a market economy. Both of these positions reflect a principal theme of the economic perspective: specifically, that social capital functions as a lubricant facilitating all types of economic exchanges (Krishna 2000). Trust is seen as promoting economic progress, progress that results from the climate of interpersonal cooperation that trust fosters (Misztal 1996, Arrow 2000). People who trust each other are thought to be more likely to interact and cooperate with one another, and these increased levels of cooperation, in turn, enhance economic exchange (Putnam 2000, Krishna 2000). Thus, trust lubricates the machinery of the market principally through promoting cooperation. But reciprocity, another component of trust, also bolsters market processes. This reciprocal aspect of trust is epitomized in the saying "you scratch my back and I’ll scratch yours.”

Some economists more fully recognize the social roots of trust (Krishna 2000, Arrow 2000). Krishna states that trust and cooperation form the core of social capital and that these concepts exist in various forms in all societies (Krishna 2000). He also acknowledges that limitations on social capital derive primarily from not knowing which individuals can be trusted and how much.

The prevailing economic perspective diverges from other perspectives in claiming that trust is a derivative of social capital. We would contend, however, that the opposite is true (viz., that social capital is a derivative of trust). Research we have examined in this paper also indicates a division within the economic perspective about the fundamental nature of trust. Brehm and Rahn (1997) have argued that trust can be seen as a manifestation or indicator of social capital, and therefore a needed commodity, 
while Krishna sees trust as part of the elemental core of social capital. On this point, it would seem that Brehm and Rahn (1997) contradict themselves. They observe that breakdowns in trust undermine social capital (Brehm and Rahn 1997), but this would seem to imply, of course, that levels of social capital are dependent on trust. It does not make sense for trust to be considered merely a manifestation of social capital when levels of social capital are themselves dependent on it. Wilson, however, also contends that social capital promotes trust and an inclusive concept of community. This split within the economic perspective suggests that some authors like Krishna are more oriented to the sociological perspective on trust, while others (Brehm and Rahn ,1997) appear to examine the trust/social capital dynamic from an exclusively economic perspective.

The Sociological Perspective: Conditions Promoting Social Relationships

The sociological perspective focuses on trust as a means for building and maintaining social relationships. From this perspective, social capital has been viewed largely as a resource used to rebuild struggling communities or to promote growth in communities that are already strong (Wilson 1997, Hearn 1997). The cultivation of social capital thus presumes a preexisting level of trust that both secures the stability of social relationships (Hearn, 1997; Misztal, 1996) and, ultimately, further increases the stock of capital available. This is reflected in Hearn's characterization that individuals' affinity for sociability constitutes the "wellspring of social capital" and in other studies that represent trust as a functional necessity for the continuance of successful social relationships (Lewis and Weigert 1985). 
It seems evident from the sociological literature that stable social relationships can not exist for long in the absence of social order. However, it is equally apparent that trust is a requirement for both social order and social relationships, and that disentangling these concepts analytically remains a difficult task. The difficulty, we believe, results from the dialectical nature of the relationship between trust and social order. Misztal (1996) represents the dialectical nature of trust as connected to an expectation about the persistence of a moral social order. She states that trust provides a crucial basis for that social order by setting the most basic limiting conditions necessary for human interactions to continue.

Misztal's (1996) definition of trust states that trust consists of believing the consequences of someone's intended action will be appropriate from our own point of view. This conception of trust as action is supported by the fact that individuals choose to act or react toward others based on the amount of trust they have placed in those persons or the level of trustworthiness the person is perceived to have demonstrated (Hardin, 2001). Luhmann (1979) also equates trust with reduction of complexity or uncertainty. The reduction of complexity is represented as a coping mechanism that allows individuals to adapt to the uncertain and complex situations they are increasingly forced to confront in modern societies (Lewis and Weigert 1985). Cook notes that trust is rooted in uncertainty as well, but suggests that trust should be defined as knowledge or belief -not action. Hardin’s (2001) argument, however, seems to contend that what actually constitutes trust is its extension manifestation into the realm of action. 
If the trust/social capital dynamic is examined even further, the literature identifies a number of components that combine to create trust (Hearn 1997, Putnam 2000, Lewis and Weigert 1985, Misztal 1996, Hardin 2001, Glaser et al. 2000). These elements include reciprocity, moral obligation, trustworthiness, social relations, cooperation, and familiarity (Misztal 1996, Hearn 1997, Hardin 2001). Although Cook generally adopts a sociological view of trust, she defines components such as trustworthiness in very economic terms. For example, she states that trustworthiness is equivalent to a person's reputation, which is an actual commodity. The degree to which individuals believe another is trustworthy is represented in the degree to which they will trust that person and actually interact with him or her. Familiarity is also seen as being linked to trustworthiness, because our familiarity with another a person will often determine the degree to which we will extend our trust (Fukuyama, 1999). Hearn (1997) provides arguably the best explanation of trust and its components, when he writes that:

Trust and trustworthiness, and the moral individuals who embody them, arise in communitarian interdependencies and social institutions that instill in people the habits of reciprocity and responsibility and the sense of moral obligation whose presence affords the strongest grounds people have for trusting one another. Social capital, those features and practices of cooperation that enable people to work together in pursuit of shared purposes, originates and becomes abundant only where trust prevails (p. 97).

This notion of trust differs markedly from the economic view that conceives of trust as a byproduct of social capital. From our perspective, it seems considerably more logical to view social capital as arising from trust. Real, although intangible, stocks of 
social capital found in communities and small groups are themselves dependent on collective resources such as trust, moral obligation, and reciprocity. Hearn's definition clearly recognizes this fact, when he describes social capital as "the practices of cooperation that enable people to work together in pursuit of shared purposes, originates and becomes abundant only where trust prevails.” Thus, social capital is itself an amalgam of group resources, whereas trust is simply a constituent resource that is used in the pursuit of common goals (Misztal, 1996).

In sum, economists tend to define trust using words such as commodity, resource, and stock. Sociologists, on the other hand, seem far more likely to describe trust using terms (e.g., cooperation, reciprocity, moral obligation, etc.) that represent the nature of interactional processes situated within the context of social relationships. This difference in terms seems to highlight both divergent conceptions and often latent disciplinary aspirations. Sociologists, for example, may wish to raise collective levels of trust in order to promote healthy relationships, and revivify communities and societies (Lewis and Weigert 1985). The hope is that vibrant communities will inevitably generate enough social capital to meet the needs of individuals and the common good. Economists, however, seem more concerned about how social capital functions to produce levels of trust sufficient to "lubricate" mechanisms crucial to the operation of a market economy. 


\section{Assessing Social Trust: A Multi-Level, Multi-Disciplinary Survey of Findings}

This section of the review summarizes what the different social sciences have learned about the causes and consequences of social trust. Corresponding to the disciplines of psychology, sociology, economics, and political science are four spheres in which trust is seen to be most important — an individual's personality, civil society, the market, and the state (Wolfe, 1989:.7). We locate our discussion about influences on trust within the context of the wider debate about social capital formation and development. As we have indicated earlier, it is difficult to distinguish factors that contribute to the development of social capital from those that contribute to the formation of social trust. Furthermore, our examination draws heavily from the literature on altruism, because trust and altruism also share similar origins.

One of the difficulties of conducting a multi-disciplinary literature survey is that it becomes necessary to pigeonhole theorists arbitrarily as either economists, sociologists, psychologists, or political scientists, when there is indeed considerable cross-fertilization of ideas across disciplinary boundaries. The reality, of course, is that these disciplines quite often shade into one another in different ways. Consider, for example, the work of Robert Putnam. Putnam first wrote about social capital and developed his 'bowling alone’ thesis in a political science journal (viz., the Journal of Democracy). However, his explanations of the societal trend towards declining civic engagement are wide-ranging, citing factors such as sub-urbanization, female labor force participation, monetary and temporal pressures, technology, and the media as influences on social capital (Putnam, 
2000:189). Obviously, such explanations have as much to do with sociology as they do with political science.

Another difficulty is that there are often as many similarities across disciplines in how researchers think about the consequences of trust as there are differences. Regardless of the discipline within which studies are nominally situated, virtually all research suggests that social trust has beneficial effects on individuals, communities, the workplace, institutions and, indeed, nations. Trust makes people healthier, happier, and more hospitable. It enables people to form meaningful connections with others from whom they can derive an array of assets, including access to jobs and knowledge of job opportunities, money, friendship, moral and social support, care, transportation, physical and mental health, and pro-democratic views (Putnam 2000).

Researchers in all of these academic fields appear to agree that trust is an “important variable affecting human relationships at all levels: relationships between governments, between minorities and majorities, buyers and sellers, patients and therapists, parents and children, and so on” (Rotter, 1980: 1). They also agree that it arises in and through social networks that infuse in people the 'social virtues' of reciprocity, honesty, obligation, reliability and altruism (Hearn 1997:97; Fukuyama, 1995:43). Our review of the consequences of trust focuses on how it affects social relationships as well as others, such as the relations between citizens and their government, buyer and seller, mother and infant, doctor and patient, and those that exist between strangers. However, we will first discuss factors that influence trust. 


\section{The Determinants of Social Trust: Individual, Group/Organization/Community, and Societal Level Influences}

\section{Research in Political Science}

Individual Level Findings. In political science, research on the determinants of social trust has focused mainly on the extent of trust in government and institutions (e.g., the media, judicial system, etc.), and the consequences of trust for democratic society. Political scientists have also turned their attention to questions such as the extent to which institutional trust is influenced by interpersonal trust. It seems unlikely that people who are generally distrustful of others with whom they interact on a daily basis will place their trust in institutions such as the government and churches. On this issue Lane writes that “if one cannot trust other people generally, one can certainly not trust those holding.......public office. Trust in elected officials is seen to be only a more specific instance of trust in humankind” (Lane 1959:.164).

Putnam has argued it is the changing lifestyle patterns of Americans that is at the root of declining trust. His analysis of lifestyle changes focuses on four types of changes : 1) those related to the pressures time and money, 2) changes related to the increase in labor force participation among women, 3) changes related to sub-urbanization, and 4) the growth of the car culture, and the influence of technology and the media.

One common view is that people are working longer and harder than they have in the past and therefore have less time to devote to activities within their communities. The evidence, however, is less compelling, for some of the busiest people are also some of the 
most dutiful in a civic sense (Putnam, 2000:191). Financial worry is another frequently cited cause of declining trust. Although more Americans are in financial debt and facing bankruptcy, Putnam finds that money pressures provide at best only a partial explanation for declining trust.

Women have historically contributed more to social capital formation than men, for it is women who have typically attended neighborhood meetings, parent-teacher conferences, and the like. As more women have entered the workforce full time, it has been predicted that they would have less time for civic engagement. The evidence suggests, however, that the relationship between civic engagement and female labor force participation is not a simple one. For women, labor force participation actually results in more, rather than less, civic participation (Putnam, 2000:202)

Residential mobility has also been linked to declining social trust. Americans are a mobile people, more mobile perhaps than any other Western nation (e.g., one in five Americans changes residence every year (Putnam, 2000:205). It is hypothesized that mobility weakens ties to our neighbors, which, in turn, lowers the overall level of community cohesion (Putnam, 2001:205). The prevalence of automobile ownership has contributed to this process by opening new job opportunities for the majority of individuals and extending friendship networks beyond the boundaries of the local neighborhood. As more people spend increasing amounts of their time traveling by car to work and other places for recreation, the time they have allotted for participation civic activities inevitably tends to shrink. (Putnam, 2000: 212).

Putnam argues that technology and the mass media exert the most pernicious effects on trust. As the impact of television has been extended to reach even rural areas 
and low-income inner city neighborhoods, a new form of entertainment has emerged and engulfed most Americans—one that doesn't involve relating to others in an immediate, face-to-face way. For some, television consumes increasing amounts of time and has become altogether a substitute for face-to-face interaction. Thus, television contributes to the privatization of leisure time and diverts individuals from various community and civic activities (Putnam, 2000:237). For this reason, it has come to be viewed as one of the major mechanisms promoting the decline of trust.

Group-Community-Organizational Findings. This is an underexamined area in the literature and consequently we did not find any prior research that speaks to it.

Societal-Level Findings. The political science literature has little to say about the causes of trust at this level. One study by Knight argues that the greater the level of social diversity within a society, the lower the level of trust (Knight in Cook, 2001:361). 5) In his work, Putnam argues that the more an individual watches television and the more he/she is a victim of crime the less likely he/she is to trust others (Putnam, 2001)

\section{$\underline{\text { Research in Psychology }}$}

Individual-Level Findings. As one would expect given the general orientation of the discipline, psychological research has largely been confined to the individual level of analysis and tends to focus on topics such as the nature of the trusting personality, processes underlying the attitude of trust, and how trust develops in children through 
socialization. Psychologists frequently use the term 'interpersonal trust' as a proxy for 'social trust' and most of their studies are based on laboratory experiments that use small samples (Lewis and Weigert 1985: 975))

Psychologists argue that the roots of trust have their origins in early childhood socialization and the parent-child bond. They see trust as a disposition that evolves over time. Erikson (1963), in his seven stages of human development, observes that the infant develops a sense of basic trust in him/herself, and in the external world, through consistent, dependable relations with a parent, most often the mother. He concludes that "mothers create a sense of trust in their children by that kind of administration which in its quality combines sensitive care of the baby's individual needs with a formal sense of personal trustworthiness” (Cook 2001:25; Erikson 1963). According to this view, trust is a learned disposition that is cultivated during early infancy in and through the actions and behavior of the child's mother. Other psychologists, such as Bowlby, have argued that the primary caregiver does not necessarily have to be the biological mother for trust to develop. However, it is clear that failure to develop a sense of trust in other people and the wider world can result in a mistrust of others that is likely to impair future personal growth. Thus, psychologists argue that trust derives from the strength of the relationship between a child and his or her early caregivers (Piliavan and Charg 1990, p.41).

One topic that has fascinated psychologists is the question of whether there is such a thing as a trusting personality (Cook 2001, p.24). Rotter's (1980) work, in particular, is relevant here. He found that the 'high truster' is likely to be a person who has experienced a happy childhood, is well adjusted and at ease in social situations, and can 
make friends easily. Such people are clearly more trusting of others and likely to give strangers the benefit of the doubt. Rotter argues that "the high truster says to him/herself, I will trust the person until I have clear evidence that he or she can't be trusted” (Rotter, 1980: 6). Conversely, the 'low truster' rejects the default assumption and instead operates on the basis of a very different rationale (viz., " I will not trust the person until there is clear evidence that he or she can be trusted”). The trusting personality is also quite tolerant of other people and respectful of their views and opinions. Piliavin and Charng found that the person who has "faith" in other people is likely to have high selfesteem, a high internal locus of control (Piliavin and Charng, 1990: 30), and a greater willingness to take risks (Swap and Johnson-George, 1982).

\section{Research in Sociology}

Individual-Level Findings. As we have indicated earlier, sociologists treat social trust as an element of social capital. The latter is constituted through individual's relations with one another and denotes the assets or benefits (e.g. information, material resources, social support, status) that flow through networks of connected and interdependent actors (Coleman, 1988: 100). Sources of social capital include family, friends, neighbors, voluntary organizations, peers, and colleagues. Trust has been invoked by sociologists as a mediator of micro, everyday, face- to- face relations (Conviser, 1973:.377). In contrast to psychologist and economists, sociologists view trust as a 'social fact' that has its

origins in group, rather than individual, behavior (Weigert and Lewis, 1985: 968). Trust, 
then, is viewed as a property embedded in the social relations that occur between people. So how do sociologists account for variations in levels of trust?

Individuals tend to trust others because they are familiar with them. But this does not explain why we trust strangers or people with whom we are unacquainted, interactions for which trust in the 'generalized other' is required. Sociologists argue that our trust of non-strangers grows from our prior knowledge of others, but such knowledge, by itself, is insufficient. We frequently trust others without knowing everything we might like to know about them (Lewis and Weigert 1985, p.970). In such a situation, it appears that we simply 'trust in trust'. Hearn, however, argues that it is easier to trust someone whom we do not know very well if that person lives or works in a place where strong norms of reciprocity or trust exist and are recognized. For example, we are likely to trust a minister, even one we don't know, because he or she works within the context of a well understood institution that most people trust. Also, we are more likely to trust a stranger if other people we know vouch for him or provide some kind of legitimation for his trustworthiness. Interpersonal trust is thus transformed into generalized social trust (Hearn ,1997:36, 98).

Sociologists extend this argument by emphasizing that people make emotional investments in others whom they trust, with the result that breakdowns in trust can often be emotionally damaging (Larzelere and Huston 1980:595). At the behavioral level, people act on the basis of their assessment of others' trustworthiness. From this perspective, trust is therefore viewed as action-oriented and the key difference between the cognitive and emotional dimensions of trust is that these are hidden while the behavioral dimension is observable. Sociologists treat the cognitive, emotional, and 
behavioral dimensions of trust as separate and distinct for analytical purposes only. In real life situations, the dimensions are inter-related and difficult to disentangle (Lewis and Weigert, 1985: 972).

Overall, there is no shortage of research in sociology with respect to this level of analyses. Different sociologists argue that there are different reasons why people trust : the more likely someone is to take risks, the more likely he/she is to trust others (Hardin in Cook, 2001:14); the more you trust another person, the greater the likelihood that person will trust you (Hardin in Cook, 2001: 3); the greater the similarity between an individual and others on specific attributes (e.g., values, interests, identities, etc.), the more likely the individual will be to trust those others (Nee and Sanders in Cook, 2001:374); individuals with lower levels of social intelligence tend to be more distrustful (Yamagashi in Cook, 2001: 121); the more familiar an individual is with another person, the easier is to trust that person (Macy and Skvoretz, 1998: 639); the greater the number of civic organizations an individual joins, the more trusting the individual will become (Stolle in Cook, 2001:205); the more repetitively individuals interact within a relationship, the more they will come to trust one another; the more certain or confident an individual is about others, the more likely he/she will be to trust others in close relationships (Sorrentino, et al., 1995: 314 \& Kee and Knox, 1970:359); the more that an individual believes his/her trust will be betrayed, the more distrustful he/she will become (Deutsch, 1958: 279); the more exchanges there are between individuals that are not explicitly contract-based the more likely they will trust each other (Molm, Peterson, and Takahashi, 1999:1396); the more an individual is able to adopt a long-range perspective, 
the more likely he/she is to trust other people in exchange relationships (Molm, Peterson, and Takahashi 1999: 888); the more individuals believe they know each other’s motivations, the more likely they are to trust each other (Brickman, et al., 1979).

GROUP OR COMMUNITY -LEVEL FINDINGS. Sociologists draw attention to the fact that a key factor influencing trust formation is the scale of social organization - in smallscale social organizations such as the family and small community it is easier for trust to develop. Conversely, in large-scale forms of human organization such as cities it is more difficult to develop and maintain trust (Putnam, 2001:205). But other characteristics of the small community apart from its scale impact trust. Specifically, Rice and Steele argue that the higher the level of ethnic diversity within a community, the lower the level of trust (Rice and Steele, 2001:406). Overall though, this analytical level is underexamined in the sociological literature.

Societal-Level Findings: Surprisingly, there is a dearth of literature relating to this level of analysis.

\section{The Consequences of Social Trust: Individual, Group/Organization/Community, and Societal Level Outcomes}

\section{$\underline{\text { Research in Political Science }}$}

Individual Level Findings. A classic study by Lane (1959) examined factors that influence popular participation in political life. This work sheds light on just how trust 
solidifies interpersonal relations. He argues that trust is an essential building block for a functioning democracy and a society based on the notion of citizenship. Citizens who Iparticipate in politics, he argues, have what he calls "faith" or trust in others. He identifies this trusting type of individual as cooperative, helpful, and caring. The presence of trust orients citizens thinking and behavior about politicians and politics in general. The trusting individual is more likely to believe that politics is fair, that elections are the medium through which the democratic voice of the people is expressed, and that voting is an important duty of every citizen. From a political science perspective then, trust or distrust have important consequences for the functioning of democracy. Distrust in other people gives rise to apathy, which in turn leads to low voter turnout. Low turnout subsequently weakens the perceived legitimacy of elected politicians who are obliged to act in the interests of the citizen. Distrust undermines the basis of citizenship by eroding people's faith in institutions that are designed to regulate and set standards for society. Without trust, societal institutions break down and their ability to act in the interests of the people is compromised. In short, a citizenry that is trusting confers legitimacy on authorities that is essential if they are to use their power and influence in the interests of the common good (Lane, 1959)

Putnam added to this characterization. He argues that trusting and trustworthy people are

"optimistic about the future, more likely to contribute to charity, to volunteer their time, to entertain strangers in their home, to work on community problems, to vote, and to be willing to serve on a jury. They are more tolerant of social and political minorities and more accepting of differing lifestyles” (in Hearn, 1997: 97).

Brehm and Rahn also present an insightful representation of how interpersonal trust, civic engagement, and confidence in government are interconnected. They argue that interpersonal trust has important consequences for levels of civic engagement and the extent to which people feel confident in government officials and politicians (Brehm and 
Rahn, 1997: 1002). And Putnam, again, writes that civic engagement, which itself is a consequence of trust, has important demand and supply side effects with respect to government. On the demand side, people who are engaged in the civic culture of their community have higher expectations of public officials and elected representatives. On the supply side, politicians and officials are induced to be more responsive to the public interest, and to govern more effectively, because they are aware that people expect them to be accountable for what they do (Putnam, 2000, p.346). This in turn cultivates greater feelings of institutional trust, a topic to which we now turn.

These two elements are important in the determination of a third variable, that of confidence in political institutions. "We believe civic engagement and generalized trust, and the dynamic that sustains them, have important consequences for the polity, specifically, citizens' confidence in political institutions ... People with a high degree of trust do not fear that they will be taken advantage of by following the rules because they expect that others will follow them too” (Brehm and Rahn 1997, p. 1003). A decreased faith in government, then, is a possible indication of diminished community involvement and even a lesser amount of social trust. Though Brehm and Rahn both admit "the total relationship between the two components of social capital and confidence in government is a more complicated problem,” their research indicates that there is a distinct correlation between the two.

Exactly what this purported relationship implies about American society is a matter of contention. According to Gallup polls, over the last 25 years people have become more trusting of some political institutions, such as the United States Supreme 
Court, state governments and local governments (Gallup 1999). However, those same people displayed different levels of trust in other government institutions, such as the legislative branch, wherein the levels of trust have consistently dropped since Jimmy Carter was in office (Gallup 1999). But while Gallup indicates that the amount of public trust in government is high, there is another contention that the reverse is true: "The national mood and trust are both up from the mid-1990s, but still just 20\% of Americans are highly satisfied with the state of the nation and only $34 \%$ basically trust the government” (Light et al. 1998, p. 1). As a result of the conflicting contentions regarding the level of trust in government institutions, it is difficult to determine from this factor alone the status of social trust.

There is also the consideration of the extent of American participation in community organizations. According to Robert Putnam in his famous article "Bowling Alone,” Americans are becoming far less involved than previous generations. "By almost every measure, Americans’ direct engagement in politics and government has fallen steadily and sharply over the last generation, despite the fact that average levels of education-the best individual-level predictor of political participation-have risen sharply throughout this period" (Putnam 1995, p. 68). In perhaps the most enlightened period in human history, in the most fiscally successful nation on the globe, the United States is becoming a breeding ground for political apathy. As participation plummets, so to may trust in government institutions.

A study of European nations whose Communist regimes failed and were being replaced by democracy by Todd Kunioka and Gary M. Woller, suggested that a high level of social capital in a nation was directly correlated with support for the new 
democratic regime (1999). This study was inspired in part by the famous 1993 publication of Robert Putnam, whose 20-year study of Italy first demonstrated the importance of social capital to the success of democratic governance. Putnam also surmised from his study that "these networks of organized reciprocity and civic solidarity, [i.e., social capital] far from being an epiphenomenon of socioeconomic modernization, were a precondition for it (Putnam 1993, p. 66). Similarly, Kunioka and Woller's study purports the theory that "The existence of trust, be it called social capital or civic community, seems to be a prerequisite for both democratic government and capitalist industry" (1999, p. 579). The two studies seem to complement each other, as both Putnam and Kunioka and Woller seem to come to the same conclusions.

Kunioka and Woller’s study suggests that social capital is the best predictor when trying to determine the likelihood of success of a newly developed democracy. "Nations populated by a reasonably active, public-spirited citizenry with a high level of trust and voluntarily associates with one another to pursue common goals will most likely succeed in democratizing efforts. Conversely, nations that lack an active civic culture will be less able to either democratize or effect economic modernization” (Kunioka and Woller 1999, p. 581). This finding also supports the aforementioned Brehm and Rahn study regarding the correlation between civic participation and social trust. Interestingly, economic indicators are far less useful in predicting the degree to which a citizenry will endorse a democratic government (Kunioka and Woller 1999, p. 594).

Overall, most of the political science research focuses on the benefits to the individual of trusting others. The more an individual trusts others the less costly his/her daily social 
interactions will tend to be (Putnam, 2001, p.288); the more tolerant and empathetic he/she will tend to be toward others (Putnam, 2001, p.289).

Group-Organizational-Community Level Findings. Generally speaking, there is a paucity of findings relating to this level of analysis that can be derived from the literature in political science. Apart from Fukuyama who argues that the lower the level of trust within a society, the more hierarchical the structure of social organization will be (Fukuyama, 1995, p.25), few political scientists have considered the role of trust in social relations at the group-organization-community level.

Societal-Level Findings. A number of findings relating to the societal-level can be generated from the political science literature most notably from the work of Francis Fukuyama and Robert Putnam. Fukuyama argues that high-trust socities are also high performing ones economically. High levels of trust in society are associated with national well-being, economic prosperity, and low transaction costs in economic exchange (Fukuyama, 1995). High trust societies also generate positive social outcomes such as a reduced need for law suits and greater tolerance among people. In such societies it is also easier to resolve collective problems (Putnam, 2001: 288).

\section{Research in Sociology}

Individual Level Findings. Sociologists sometimes differ in the meaning of trust but they all seem to agree that it has important consequences for the functioning of society (Cook 
2001, p1). For one thing, it is the glue the makes co-operation, solidarity and altruism possible. If people don't trust people known to them as well as the stranger they don't know, they are less likely to co-operate with others. Trust brings us closer to people and provides the starting point for meaningful relationships. In this sense then, trust can be considered as the building block of social solidarity and its absence as a signifier of social breakdown. People that are not inclined to trust others are more likely to have a smaller circle of people with whom they interact and to be more solitary (Cook 2001, p.1).

Coleman argues that the presence of trust between people opens up greater opportunities for mutual aid, reciprocity, and solidarity (Hearn 1997, p.35). He argues that it is in micro-level social relationships formed with family, friends and neighbors that people develop and cultivate trust and, in turn, the ability to generalize this norm across other more impersonal relationships outside their primary social groups such as social groups in schools (Hearn 1997, p.35).

Social trust has a profound impact on the development of children. Research by Ann Meier indicates that courses of action taken by parents to promote social capital play a significant role in determining the academic success of children. Meier's thesis discusses the ways in which parents can promote social capital, and in what ways the social capital created affects children in the classroom. She begins her thesis with the hypothesis that "families use their income to invest in the social capital of their children" (Meier 1999, p. 21). Family income, then, can be used to establish residential stability and to enroll children in parochial schools, although the latter condition is weakly correlated with income. These elements of social capital, namely intact family structure, parochial school attendance, and residential stability, have five major consequences: 
greater intergenerational closure, higher parental involvement in school, higher levels of extracurricular activities participation on behalf of the child, increased parent-child interaction, and a stronger student-teacher relationship. All of these outcomes are indicative of superior academic achievement (Meier 1999, p.20).

Meier's research suggests that the greater the parents' income and the higher their level of education, the greater the intergenerational closure within the family. "Higher SES parents are more likely to know more of their children's friends and, in turn, the parents of those friends” (Meier 1999, p. 24). Parental investment in social capital directly impacts the connectedness of the network of children and parents. Greater intergenerational closure can promote a heightened sense of trust, resulting in networks of people that can know and can rely on each other.

"All of the social capital forms are related to PTO participation. Parents from all non-intact family structures are less likely to participate in a PTO as are those who more frequently. Parents who send their children to parochial school are much more likely to be PTO members” (Meier 1999, p. 26). Parent-teacher organizations are a manifestation of social capital between parents, students, and teachers. Voluntary participation in this type of organization requires the adults to commit their time and energy to a common goal, the improved educational experience of the children. Active participation in this association will also create more social capital between the parents, teachers, and students.

"The probability of participating in extracurricular activities increases with family income and parental education” (Meier 1999, p. 26). As mentioned before, family income can be used to increase social capital, an intricate part of social trust. This social 
capital is used to encourage children to participate in extracurricular activities. Like PTOs, this has a reciprocal benefit. While on the one hand extracurricular activities can make children more well-rounded and increase their social network of friends and acquaintances, such activities at the same time further increase social capital among those who actively participate in them.

Meier also indicates that "parent-child interaction increases with family income and parental education" (ibid, p. 27). Among the benefits of this occurrence is the increased socialization of the child. Extended interaction between parents and children will result in a more thorough communication of values. Informal social controls can be more readily used instead of formalized ones. The increased interaction allows for children to learn how to act in society from their parents, and parents are able to more easily pass on the values necessary for society to work.

Lastly, Meier's research indicates that "student-teacher relationships improve with father's education and number of siblings” (ibid, p. 27). The second factor has obvious implications with regard to social capital. Previous siblings help pave the way to developing social capital between teacher and students. Having subsequent children in the teacher's class has the advantage of previously-established connections between parents and teacher, and familiarity between teacher and family. Social capital, having already been established to some degree, increases further with extended interaction.

All five of these outcomes of social capital between parents, teachers and students generally lead to one outcome: improved academic performance. Meier notes that "GPA increases with parental income and education ... GPA is higher for those who attend parochial school and those who have moved once, and it decreases for those in non-intact 
family forms" (1999, p. 28). We can infer from the aforementioned observations that social capital has an indirect positive impact on social capital, promoting relationships between parents, teachers, and children. The bottom line with regard to social capital and children is that a heightened amount of the former results in a more well-rounded, better socialized, superiorly-performing student.

\section{$\underline{\text { Research in Economics }}$}

Individual Level Findings. At first glance, it appears somewhat strange that an economist would show any interest in an inquiry about a 'social thing' like trust. Sociologists argue that "trust is to society what contract is to the market" (Hearn 1997, p.34). The notion that trust plays a role in economic life seems anathema to many economists. This is because one of the goals of the market is to 'free' people from any sense of obligation to or trust in one another and to maximize opportunities for the pursuit of rational selfinterest (Titmuss 1971, p.239, Fukuyama 1995, p.33). Economists tend to view buyers and sellers as rational and calculating actors who are out to maximize self-interest and are 'free to choose' the most efficient means of attaining their desired ends. However, people are not 'angels', as James Madison argued, and consequently more and more economists have come to view trust as an 'externality', that is, as a moral asset, that makes market exchange less prone to risk and uncertainty. In short, they see it as a good or commodity in itself that reduces the 'transaction costs' associated with doing business with strangers (Hearn 1997, p.103 and p.129, Wolfe 1989, p.7, Fukuyama 1995, p.27). 
Granovetter critiques this traditional 'rational' model by embedding economic behavior in social relations and by arguing that too little emphasis is paid to reliability and trust in various everyday economic transactions (Granovetter 1985, p.482). Lewis and Weigert, writing along similar lines, argue that economists tend to have an 'overrationalized' view of trust and that they give insufficient recognition to the role of trust in a functioning money economy (Lewis and Weigert 1985, p.976). Many people trade with sellers whom they trust to be honest in their dealings, based on prior experience of them, when it comes to buying a car for instance. Trust then can be seen as a reducer of uncertainty and risk in the market. The saying 'better the devil you know than the devil you don't know' captures this basic point. Gambetta argues that a car dealer works to frame the presentation of his/her self as a trusting one, in the hope that customers will return again and again and that he/she will establish him/herself as a reputable dealer (Gambetta 1988, p.59). Banks rely on cashiers whom they can trust to handle money on a day-to-day basis and to reduce the risk of fraud or embezzlement.

Since the 1970s, the role of trust in mediating market behavior has gained more prominence as economists seek to make explicit the values that underlie market behavior (Titmuss 1971, p.199, Granovetter, 1985, p.487). Titmuss's seminal study on the marketization of blood giving in America yields important insights about the role of altruism and trust in market behavior. Titmuss concluded that the commodification of blood is bad for the individual and for society because it "represses the expression of altruism, erodes sense of community.....(and) subjects critical areas of medicine to the laws of the market” (Titmuss 1971, pp.245-246). 
Economic institutions have developed their own way of rationalizing trust where calculating, interpersonal trust isn’t feasible as a basis for human interaction. Consider, for instance, the use of credit cards. Shop owners and business people view the credit card as a proxy for money because they trust that the card is backed up somewhere by a bank with money to pay (Lewis and Weigert 1985,p.974). Credit cards companies rely on trust in the 'generalized other' for their product to function and to purge uncertainty from economic transactions. The ubiquity of credit cards today suggests that they work as substitutes for interpersonal trust between the consumer and seller. From the economists' perspective, trust makes market behavior possible by allowing people to exchange money, a scarce resource, without great levels of risk being incurred. Other economists have looked at the role of trust in employee-employer relationships. Employers that provide job security and good working conditions are more likely to be trusted than employers that don't. This in turn cultivates greater company loyalty among the workers which is likely to lead to higher profits and lower costs (Cook 2001, p.xxiv). In this sense, trust can be viewed as a form of human capital, a good in and of itself, that can enhance job performance and satisfaction. Economists working out of this way of thinking, see trust as a commodity that can be bought through monetary incentives such as good wages and other work-related benefits (Cook 2001, p.21)

\section{Assessing the Strengths and Weaknesses of Research on Social Trust}

An effective literature review provides the reader at least with a relatively comprehensive survey of prior research on the topic of interest. But it must do more than that. It should also summarize the existing research findings in a succinct and compelling 
fashion and, whenever possible, identify gaps in the literature that invite more inquiry and research. For the sake of convenience, all the empirical findings reported earlier have been summarized in the form of two separate inventories of propositions (see Tables 1 and 2) that classify findings by level of analysis (e.g., individual level; group, organizational, or community level; and societal level) and denote the amount of empirical support each has received. Studies were also categorized by academic discipline and presented in an additional table (Table 3).

Tables 1, 2, and 3 about here.

It is apparent from the patterns of findings reported in Tables 1 and 2 that the moist empirical research has been limited to individual level analyses. Nearly eight per cent $(18 / 23=78.3 \%)$ of the findings from research that examined factors influencing social trust (Table 1) derive from studies that were conducted at the individual level, as did close to sixty per cent $(15 / 26=57.7 \%)$ of the findings from research that studies the effects of trust on other variables (Table 2). Less than twenty per cent (4/23=17.4\% Table $1 ; 4 / 26=15.4 \%$, Table 2) of the findings presented in Tables 1 and 2 reflected research conducted at the group or community level. Only one finding from Table $1(1 / 26=4.3 \%)$ represents research that focused on the societal level; however, several findings (7/26=26.9\%) from Table 2 derive from studies that examined how trust exerts its influence at the societal level. 
Table 1

SOCIAL TRUST AS A DEPENDENT VARIABLE:

AN INVENTORY OF PROPOSITIONS

\section{INDIVIDUAL-LEVEL FINDINGS}

1) The more likely someone is to take risks, the more likely he/she is to trust others (Hardin in Cook, 2001:14). * SOC

1a) The more risk averse an individual is, the less likely he/she will be to trust others (Swap and Johnson-George, 1982). ?* PSYCH

2) The more you trust another person, the greater the likelihood that person will trust you (Hardin in Cook, 2001: 3). SOC

3) The greater the similarity between an individual and others on specific attributes (e.g., values, interests, identities, etc.), the more likely 
the individual will be to trust those others (Nee and Sanders in Cook, 2001:374). SOC

4) The more an individual watches television, the less likely he/she is to trust others and participate in the civic life of their community (Putnam, 2000, p.235). POLSCI

5) Individuals with lower levels of social intelligence tend to be more distrustful (Yamagashi in Cook, 2001: 121). SOC

6) The more familiar an individual is with another person, the more likely he/she is to trust that person (Macy and Skvoretz, 1998: 639).* SOC

7) The greater the number of civic organizations an individual joins, the more trusting the individual will become (Stolle in Cook, 2001:205).

8) The more certain or confident an individual is about others, the more likely he/she will be to trust others in close relationships (Sorrentino, et al., 1995: 314 \& Kee and Knox, 1970:359). SORRENTINO (PSYCH) KEE AND KNOX (SOC).

9) The more that an individual believes his/her trust will be betrayed, the more distrustful he/she will become (Deutsch, 1958: 279). PSYCH

10) The more an individual is able to adopt a long-range perspective the more likely he/she is to trust others in exchange relationships (Molm, Peterson, and Takahashi, 1999:888). SOC

11) The more individuals believe they know each other's motivations, the more likely they are to trust each other (Brickman, Becker and Castle, 1979:520).

\section{PSYCH}

12) The more an individual is a victim of crime the less likely he/she is to trust others (Putnam, 2001:138). POLSCI

13) The more equality there is between people in an exchange relationship the more likely they are to trust each other (Molm, Takahashi, and Peterson 2000:1397). SOC

14) The more frequent exchange relationships are the more likely trust is to develop within them (Lawler and Yoon,1996:89) SOC 


\section{GROUP OR COMMUNITY -LEVEL FINDINGS}

Table 1, cont.

1) The more a community shares a common set of moral values, the greater the likelihood that a high level of collective trust will arise (Fukuyama,1995:153).* POLSCIISOC

2) The larger the size of the group, organization, or community, the less likely individual members will trust one another (Putnam, 2001:205). POLSCI

3) The higher the level of uncertainty in exchange relationships, the lower the level of interpersonal trust (Kollock, 1994: 313). SOC

4) The higher the level of ethnic diversity within a community, the lower the level of trust (Rice and Steele, 2001:406; Putnam, 2000: 400). ** Rice and Steele (SOC), Putnam (POLSCl)

\section{SOCIETAL-LEVEL FINDINGS}

1) The greater the level of social diversity within a society, the lower the level of trust (Knight in Cook, 2001:361) POLSCI

* Denotes finding that has been reported in only one study. 
Table 2

SOCIAL TRUST AS AN INDEPENDENT VARIABLE:

AN INVENTORY OF PROPOSITIONS

\section{INDIVIDUAL-LEVEL FINDINGS}

1) The more distrustful an individual is of others, the less likely he/she is to interact with them (Yamagashi, 2001:121). PSYCH

2) The more distrustful an individual is of others, the poorer he/she will be at judging their trustworthiness (Yamagashi, 2001:139).* PSYCH

3) The more trusting an individual is, the more likely he/she will be to join voluntary associations (Stoole, 2001:206).* SOC

4) The less trust there is between individuals, the more likely they are to be suspicious of each other (Kramer, 1995:13). PSYCH

5) The less trusting an individual is of others, the more likely he/she is to engage in anti-social behavior (Gurtman, 1992:991). PSYCH

6) The more trusting an individual is the less susceptible he/she to developing interpersonal problems (Gurtman, 1992:989). PSYCH

7) The more an individual trusts his/her "significant other", the more likely he/she is to have a fulfilled relationship (Rempel, et al., 1985:95). PSYCH

Table 2, cont.

8) The more an individual trusts others, the less costly his/her daily social interactions will tend to be (Putnam, 2001:288). POLSCI 
9) The more an individual trust others, the more tolerant he/she will tend to be toward them (Putnam, 2001:289). POLSCI

10) The more an individual trusts others, the more empathetic he/she will tend to be toward them (Putnam, 2001:289). POLSCI

11) The more an individual trusts others, the more easily he/she can recruit them to participate in community organizations (Putnam, 2001: 289). POLSCI

12) The more trusting an individual is, the more easily he/she can cooperate with others (Swap and Johnson-George, 1982:306). PSYCH

13) The more an individual is a victim of crime the less likely he/she is to trust others (Putnam, 2001:138). POLSCI

\section{GROUP, ORGANIZATION, OR COMMUNITY -LEVEL FINDINGS}

1) The higher the level of trust within a group, community, or organization, the more easily members can cooperate to achieve shared goals (Hardin, 2001:

23).** SOC

2) The lower the level of trust within a community, the fewer voluntary associations there are likely to be (Putnam, 2000: 401).

3) The higher the level of trust within an economic organization, the more productive the organization becomes (Fukuyama, 1995: 7; Miller, 2001:329).*

POLSCI (FUKUYAMA), SOC (MILLER)

\section{SOCIETAL-LEVEL FINDINGS}

1) The higher the level of trust within a society, the higher the level of a nation's well-being (Fukuyama, 1995: 7).* POLSCI

2) The higher the level of trust within a society, the higher the level of economic prosperity (Fukuyama, 1995: 357 ). ${ }^{*}$ POLSCI

3) The higher the of trust within a society, the lower the level of transaction costs within its economic exchange system (Fukuyama, 1995: 150). * POLSCI

4) The lower the level of trust within a society, the more hierarchical the structure of social organization (Fukuyama, 1995: 25). ${ }^{*}$ POLSCI

5) The higher the level of trust within a society, the less likely a "culture of litigation" will develop (Fukuyama, 1995: 310). * POLSCI 
6) The higher the level of trust within a society, the more tolerance there will be for differences among people (Putnam, 2001:289). ${ }^{*}$ POLSCI

7) The higher the level of trust within a society, the more easily collective problems can be resolved (Putnam, 2001: 288). ${ }^{\star \star \star}$ POLSCI

8) The higher the level of trust in society the more egalitarian it is (Wilkinson, Kawacki, and Kennedy, 1998:580). *SOC

9) The higher the level of trust in society the healthier it is (Wilkinson, Kawacki, and Kennedy, 1998:580). *SOC

Table 2, cont.

* Denotes finding that has been reported in only one study.

** Denotes finding reported in at least two studies.

$\star$ Denotes finding reported in three or more studies. 


\section{REFERENCES}

Arrow, K.J. 2000. “Observations on Social Capital” in P. Dasgupta \& I. Serageldin

(Eds.), Social Capital: A Multifaceted Perspective (pp. 3-5). Washington, D.C.:

The World Bank.

Bellah, R. Madsen, R., Sullivan, W.M. Swidler, A. and Tipton, S.M. 1992. The Good

Society. New York: Vintage Books.

Brehm, J. and Rahn, W. 1997. "Individual-Level Evidence for the Causes and

Consequences of Social Capital” in American Journal of Political Science, 41: 999-1023.

Brickham, P., Becker, L.J. and Castle, S. 1979. Journal of Personality and Social

Psychology. 37,4:515-521. 
Cole, R.L. 1973. “Toward a Model of Political Trust : A Causal Analysis” in American Journal of Political Science. 17:809-817.

Coleman, J.S. 1988. "Social Capital in the Creation of Human Capital” in American Journal of Sociology. 94:95-120.

Conviser, R.H. 1973. “Toward A Theory Of Interpersonal Trust” in Pacific Sociological Review. 16.

Cook, K.S. 2001. Trust In Society. New York: Russell Sage Foundation.

Cook, K.S. and Emerson, R. 1978. Power, Equity And Commitment in Exchange

Networks. American Sociological Review. 43:721-739.

Deutsch M. 1958. Trust and Suspicion. Journal of Conflict Resolution. 2:265-279.

Erikson, E. 1963. Childhood and Society. $2^{\text {nd }}$ ed. New York: Norton.

Fukuyama, F. 1995. Trust: The Social Virtues and the Creation of Prosperity. New York:

The Free Press.

Fukuyama, F. 1999. “The Great Disruption: Human Nature and the Reconstitution of Social Order" in The Atlantic Monthly 272: 55-80.

Gambetta, D. ed. 1988. Trust: Making and Breaking Cooperative Relations. Oxford: Blackwell.

Glaser, E.L., Laibson, D.I., Scheinkman, J.A., and Soutter, C.L. 2000. Measuring Trust. Quarterly Journal of Economics. 115,3:811-846.

Granovetter, M. 1985. “Economic Action and Social Structure: The Problem of Embeddedness” in American Journal of Sociology. 19: 481-510.

Gurtman, M.B. 1992. Trust, Distrust, and Interpersonal Problems: A Circumplex Analysis. Journal of Personality and Social Psychology. 62,6:989-1002. 
Hall, P.A. 1990. "Social Capital in Britain” in British Journal of Political Science. 29: 419-461.

Hardin, R. 2001. “Conceptions and Explanations of Trust” in K.S. Cook (Series Ed. \& Vol. Ed.), Trust in Society: Vol. 2. The Russell Sage Foundation Series on Trust (1 ${ }^{\text {st }}$ ed., pp. 3-39). New York: Russell Sage Foundation.

Hearn, F. 1997. Moral Order and Social Disorder: The American Search for Civil Society. New York: Aldine de Gruyter.

Johnson-George, C. and Swap, W.C. 1982. Measurement of Specific Interpersonal Trust: Construction and Validation of a Scale to Assess Trust in a Specific Other. Journal of Personality and Social Psychology. 43,6:1306-1317.

Kee, H.W. and Knox, R.E. 1970. Conceptual and methodological considerations in the study of trust and suspicion. Journal of Conflict Resolution. 14:357-356.

Knight, J. 2001. "Social Norms and the Rule of Law: Fostering Trust in a Socially Diverse Society” in K.S. Cook (Series Ed. \& Vol. Ed.), Trust in Society: Vol. 2. The Russell Sage Foundation Series on Trust (1 $1^{\text {st }}$ ed., pp. 354-373). New York: Russell Sage Foundation.

Kollock, P. 1994. The Emergence of Exchange Structures: An Experimental Study of Uncertainty, Commitment, and Trust. American Journal of Sociology. 100,2:313-345.

Kramer, R.M. 1999. Trust and Distrust In Organizations: Emerging Perspectives, Enduring Questions. Annual Review of Psychology. 50:569-598.

Kramnick, I (ed.). 1987. The Federalist Papers. Harmondsworth: Penguin. Krishna, A. 2000. “Creating and Harnessing Social Capital” in P. Dasgupta \& I. Serageldin (Eds.), Social Capital: A Multifaceted Perspective (pp. 71-93). 
Washington, D.C.: The World Bank.

Kunioka, Todd, and Gary M. Woller. 1999. “In (a) Democracy We Trust: Social and Economic Determinants of Support for Democratic Procedures in Central and Eastern Europe.” In The Journal of Socio-Economics 28: 577-596.

Lane. R.E. 1959. Political Life: Why People Get Involved in Politics. Glencoe: The Free Press.

Larzelere, R.E. and Huston, T.L. 1980. The Dyadic Trust Scale: Toward Understanding Interpersonal Trust in Close Relationships. Journal of Marriage and The Family. 595-604. Lawlor, E.J. and Yoon, J. 1996. Commitment In Exchange Relations: Test Of A Theory Of Relational Cohesion. American Sociological Review. 61:89-108.

Levi, M. 1999. When Good Fences Make Good Neighbors: A Transaction Cost Approach To Trust And Distrust. Russell Sage Foundation Paper from the Working Group on the Construction and Maintenance of Trust.

Lewis, D.J., Weigert, A.J. 1985a. "Social Atomism, Holism and Trust” in The Sociological Quarterly. 26:455-471.

Lewis, D.J. and Weigert, A. 1985b. “Trust as a Social Reality” in Social Forces. 63:969985.

Luhmann, N. 1979. Trust and Power. London: Pitman.

Macy, M.W. and Skvoretz, J. 1998. The Evolution of Trust and Cooperation Between Strangers : A Computational Model. American Sociological Review. 63,5:638-660. Miller, Gary. 2001. "Why Is Trust Necessary in Organizations? The Moral Hazard of Profit Maximization” in K.S. Cook (Series Ed. \& Vol. Ed.), Trust in Society: Vol. 2. The 
Russell Sage Foundation Series on Trust ( $1^{\text {st }}$ ed., pp. 307-331). New York: Russell Sage Foundation.

Misztal, B. 1996. Trust in Modern Societies. Cambridge: Polity.

Molm, L. Peterson, G. and Takahashi, N. 1999. Power in Negotiated And Reciprocal Exchange. American Sociological Review. 64:876-890.

Molm, L., Takahashi, N. and Peterson, G. 2000. Risk and Trust in Social Exchange : An Experimental Test of a Classical Proposition. American Journal of Sociology. 105,5:1396-1427.

Moore, David W. 1999. “Public Trust in Federal Government Remains High.” The Gallup Organization Poll Analyses. www.gallup.com/poll/releases/pr990108.asp.

National Bureau of Economic Research. (1999, July). What is Social Capital? The Determinants of Trust and Trustworthiness. (Working Paper No. 7216)).

Nee, V. and Sanders, J. 2001. “Trust in Ethnic Ties: Social Capital and Immigrants” in K.S. Cook (Series Ed. \& Vol. Ed.), Trust in Society: Vol. 2. The Russell Sage Foundation Series on Trust (1 ${ }^{\text {st }}$ ed., pp. 374-392). New York: Russell Sage Foundation.

Orwell, J. and Dawes, R.M. 1991. A “Cognitive Misers” Theory of Cooperators Advantage. American Political Science Review. 85,2:515-528.

Paxton, P. 1999. “Is Social Capital Declining in the United States ? A Multiple Indicator Assessment” American Journal of Sociology. 105: 88-127.

Piliavin, J.A. and Charng, H.W. 1990. “Altruism: A Review of Recent Theory and Research” Annual Review of Sociology. 16: 27-65.

Portes, A. 1998. Social Capital: Its Origins and Applications in Modern Sociology. Annual Review of Sociology. 24:1-24. 
Putnam, R. 2000. Bowling Alone : The Collapse and Revival of American Community. New York: Simon and Schuster.

Putnam, R. 1995. “Bowling Alone: America’s Declining Social Capital” in Journal of Democracy. 6: 65-78.

Putnam, Robert D. 1993. Making Democracy Work: Civic Traditions in Modern Italy. Princeton, NJ: Princeton University Press.

Rempel, J.K., Holmes, J.G., and Zanna, M.P. 1985. Trust in Close Relationships. Journal of Personality and Social Psychology. 49,1:95-112.

Rice, Tom W. and Steele, Brent. 2001. White Ethnic Diversity and Community Attachment in Small Iowa Towns. Social Science Quarterly. 82:397-407.

Roshwald, M. 1981. "Peace and Trust: The Egyptian-Israeli Case”. Social Science. 56. Ross, C.E., Pribesh, S. and Mirowsky, J. 2001. Powerlessness and the Amplification of Threat: Neighborhood Disadvantage, Disorder, and Mistrust. American Sociological Review. 66:568-591.

Rotter, J.B. 1980. “Interpersonal Trust, Trustworthiness, and Gullibility”. American Pscyhologist. 35: 1-7.

Shoop, Tom. 2001. "High level of trust in government may be hard to sustain. Government Executive Magazine. www.govexec.com/dailyfed/1101/112701ts1.htm. Sorrentino, R.M., Hanna, S.E., Holmes, J.G., and Sharp, A. 1995. Uncertainty Orientation and Trust in Close Relationships: Individual Differences in Cognitive Styles. Journal of Personality and Social Psychology. 68,2:314-327. 
Stolle, D. 2001. "Clubs and Congregations: The Benefits of Joining an Association” in K.S. Cook (Series Ed. \& Vol. Ed.), Trust in Society: Vol. 2. The Russell Sage Foundation Series on Trust ( $1^{\text {st }}$ ed., pp. 374-392). New York: Russell Sage Foundation.

Sullivan, J.L. and Transue, J.E. 1999. "The Psychological Underpinnings of Democracy: A Selective Review of Research on Political Tolerance, Interpersonal Trust, and Social Capital”. Annual Review of Psychology. 50:625-650.

Sztompka, P. 1999. Trust: A Sociological Theory. Cambridge: Cambridge University Press.

Titmuss, R. 1971. The Gift Relationship: From Human Blood to Social Policy. New York: Randon House.

Troy, P. 2002. Distrust and the Development of Urban Regulations. Russell Sage Foundation Paper from the Working Group on the Construction and Maintenance of Trust.

Wolfe, A. 1989. Whose Keeper? Social Science and Moral Obligation. Berkeley: University of California Press.

Wilson, P.A. 1997. "Building Social Capital: A Learning Agenda for the Twenty-first Century” in Urban Studies. 34(5-6):745-760.

Wilkinson, Richard G., Kawachi, Ichiro, and Kennedy, Bruce P. 1998. "Mortality, the social environment, crime and violence” in Sociology of Health \& Illness 20,5: 578-597. Wilson, William Julius. 1996. When Work Disappears: The World of the New Urban Poor. New York, NY: Vintage Books.

Wuthnow, Robert. 1998. Loose Connections: Joining Together in America's

Fragmented Communities. Cambridge, MA: Harvard University Press. 
Yamagashi, Toshio. 2001. "Trust as a Form of Social Intelligence” in K.S. Cook (Series

Ed. \& Vol. Ed.), Trust in Society: Vol. 2. The Russell Sage Foundation Series on Trust ( $1^{\text {st }}$ ed., pp. 121-147). New York: Russell Sage Foundation.

Websites:

“Deconstructing Distrust: How Americans View Government.” The Pew Research

Center. www.people-press.org/trustrpt.htm.

Government Executive Magazine. www.govexec.com/dailyfed/1101/112701ts1.htm. 